University of Nebraska - Lincoln

DigitalCommons@University of Nebraska - Lincoln

Egyptian textiles and their production: 'word' and 'object'

Centre for Textile Research

$3-2-2020$

\title{
A new kind of loom in early Roman Egypt? How iconography could explain (or not) papyrological evidence
}

Maria Mossakowska-Gaubert

University of Copenhagen

Follow this and additional works at: https://digitalcommons.unl.edu/egyptextiles

Part of the Africana Studies Commons, African Languages and Societies Commons, Classical Archaeology and Art History Commons, Fiber, Textile, and Weaving Arts Commons, History of Art, Architecture, and Archaeology Commons, and the History of Science, Technology, and Medicine Commons

Mossakowska-Gaubert, Maria, "A new kind of loom in early Roman Egypt? How iconography could explain (or not) papyrological evidence" (2020). Egyptian textiles and their production: 'word' and 'object'. 2. https://digitalcommons.unl.edu/egyptextiles/2

This Article is brought to you for free and open access by the Centre for Textile Research at DigitalCommons@University of Nebraska - Lincoln. It has been accepted for inclusion in Egyptian textiles and their production: 'word' and 'object' by an authorized administrator of DigitalCommons@University of Nebraska - Lincoln. 


\title{
A new kind of loom in early Roman Egypt? How iconography could explain (or not) papyrological evidence
}

\author{
Maria Mossakowska-Gaubert
}

The question of the different kinds of loom used in ancient Egypt is one of the most crucial issues to understanding the evolution of textile production and its technological development in the Nile Valley. However, sources concerning looms (archaeological, iconographic and written) from the Pharaonic era until the Arab medieval period are meagre, and many research questions remain open. ${ }^{1}$ This article is an attempt at a new interpretation of some evidence, particularly iconographic and papyrological, which could add new data to the study of weaving looms used in Egypt of the early Roman period $\left(1^{\text {st }}-2^{\text {nd }}\right.$ century $\left.A D\right)$.

\section{Looms in ancient Egypt - an overview ${ }^{2}$}

The current state of research suggests that the horizontal loom, known as early as the Neolithic period, is the oldest type of loom used in Egypt. In this loom, the warp is mounted horizontally between two beams and is held in tension by pegs in the ground. The weaver kneels and has to move forward as the fabric progresses, either sitting beside the tissue, or perhaps on it.

It is generally considered that the vertical two-beam loom was introduced into Egypt during the New Kingdom and partly replaced the ground loom. In this loom the warp is held in tension between two beams fixed in an upright frame. According to Gillian Vogelsang-Eastwood's interpretation, the tension of the warp was controlled by turning or lowering a movable cross-beam. ${ }^{3}$ The weaver was seated when starting, but as the work progressed, he/she had to stand in front of the loom.

It seems that in Roman times a new version of the twobeam loom appears in Egypt. ${ }^{4}$ Analyses of archaeological textiles from Egypt, iconographic material from the western part of the Roman Empire, ${ }^{5}$ as well as ethnographic evidence, have led Martin Ciszuk and Lena Hammarlund to conclude that the Roman two-beam loom had both beams

Published in Maria Mossakowska-Gaubert, ed., Egyptian Textiles and Their Production: 'Word' and 'Object' (Hellenistic, Roman and Byzantine Periods) (Lincoln, NE: Zea Books, 2020). doi 10.32873/unl.dc.zea.1079

The article was written within the framework of the MONTEX project. This project has received funding from the European Union's Horizon 2020 research and innovation programme under the Marie Skłodowska-Curie grant agreement No 701479.

1. For studies laying out the current state of research on this topic, see: Archaeological and iconographic evidence (from the Pharaonic to the Byzantine period): Kamp \& Vogelsang-Eastwood 2001; Ciszuk \& Hammarlund 2008; Sigl 2016; Sigl 2020. Papyrological documentation (Hellenistic and Roman periods): Wpiszycka 1965, especially p. 48-54; Droß-Krüpe 2011, especially p. 38-42.

2. See also the article by Johanna Sigl, in this volume (Sigl 2020).

3. Vogelsang-Eastwood 200o, p. 277-278; Kamp \& Vogelsang-Eastwood 2001, p. 405-426, especially p. 413. However, M. Ciszuk and L. Hammarlund are more reserved about this issue and consider that "the depictions do not allow any secure conclusions about how the warp was mounted or the shedding mechanism constructed" (Ciszuk \& Hammarlund 2008, p. 125).

4. I would like to thank Anne Kwaspen for discussing this topic with me and for her valuable technical remarks about the Roman loom.

5. Based mainly on John-Peter Wild's study (Wild 1992). 


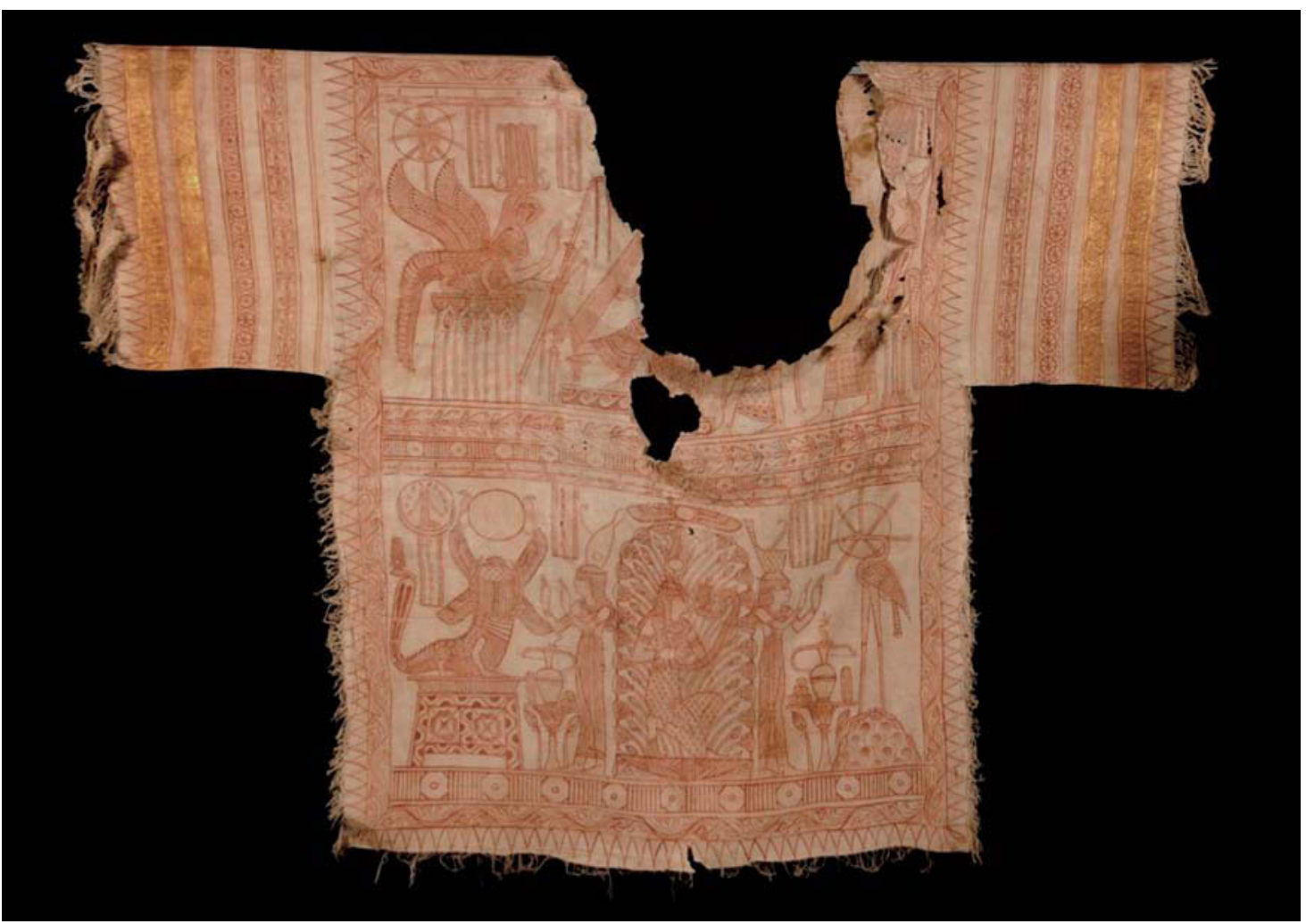

Figure 1a. Tunic found in a sarcophagus excavated at Sakkara in 1922, now preserved in the Egyptian Museum, Cairo (JE 59117), side B ( $2^{\text {nd }}$ century AD). (Photo: Ahmed Amin (C Egyptian Museum, Cairo).

revolving, and the warp fastened with a twined starting cord. ${ }^{6}$ The weaver could be seated throughout the weaving process.

Following the results of Johanna Sigl's research, ${ }^{7}$ one can suppose that at least from the $6^{\text {th }}$ century AD a vertical loom, which use require a special pit, was known in Egypt. However, it has not yet been determined whether this loom had a simple warp, or a tubular warp (two-beam and/or three-beam loom): most likely, looms of various kinds were used in these 'loom-pits'.

As regards the warp-weighted loom, it was in use on sites where a non-Egyptian population was dominant: those founded by Greeks in the Ptolemaic period or constructed by the army during the Roman era. It could be also connected with the local production of cotton fabric in Kharga and Dakhleh Oasis as well in Nubia, - the only regions in Egypt where cotton grew at least from the $2^{\text {nd }}$ century AD. ${ }^{8}$ In the warp-weighted loom, the warp is fixed to the upper beam and is held in tension by loom weights. The weaver works most of the time standing at the loom.

Finally, the tablet loom, well known during the Roman and Byzantine eras, has been already used in Egypt at the beginning of the 1st millennium BC, or perhaps even in earlier period. ${ }^{9}$ It is small, ease to carry and can be set up anywhere.

It is obvious that at various epochs several kinds of weaving loom could be used simultaneously: the introduction of a new type of loom did not exclude the use of older loom models and versions.

\section{The loom in iconography: missed evidence from Roman Egypt}

It is surprising to note that the only representation of a loom identified until now from Roman Egypt does not

6. Ciszuk \& Hammarlund 2008, p. 125. However, according to E. Broudy's interpretation, "the top beam of the Roman loom probably did not revolve but could be lowered though slots in the uprights as the weaving progressed and was wound on the lower beam" (Broudy 1979, p. 47).

7. Sigl 2016; Sigl 2020.

8. See especially Wild et al. 2008, p. 144. About cotton in Egypt see also Gradel et al. 2012, and the article by Fleur LetellierWillemin, in this volume (Letellier-Willemin 2020).

9. Broudy 1979, p. 31. 


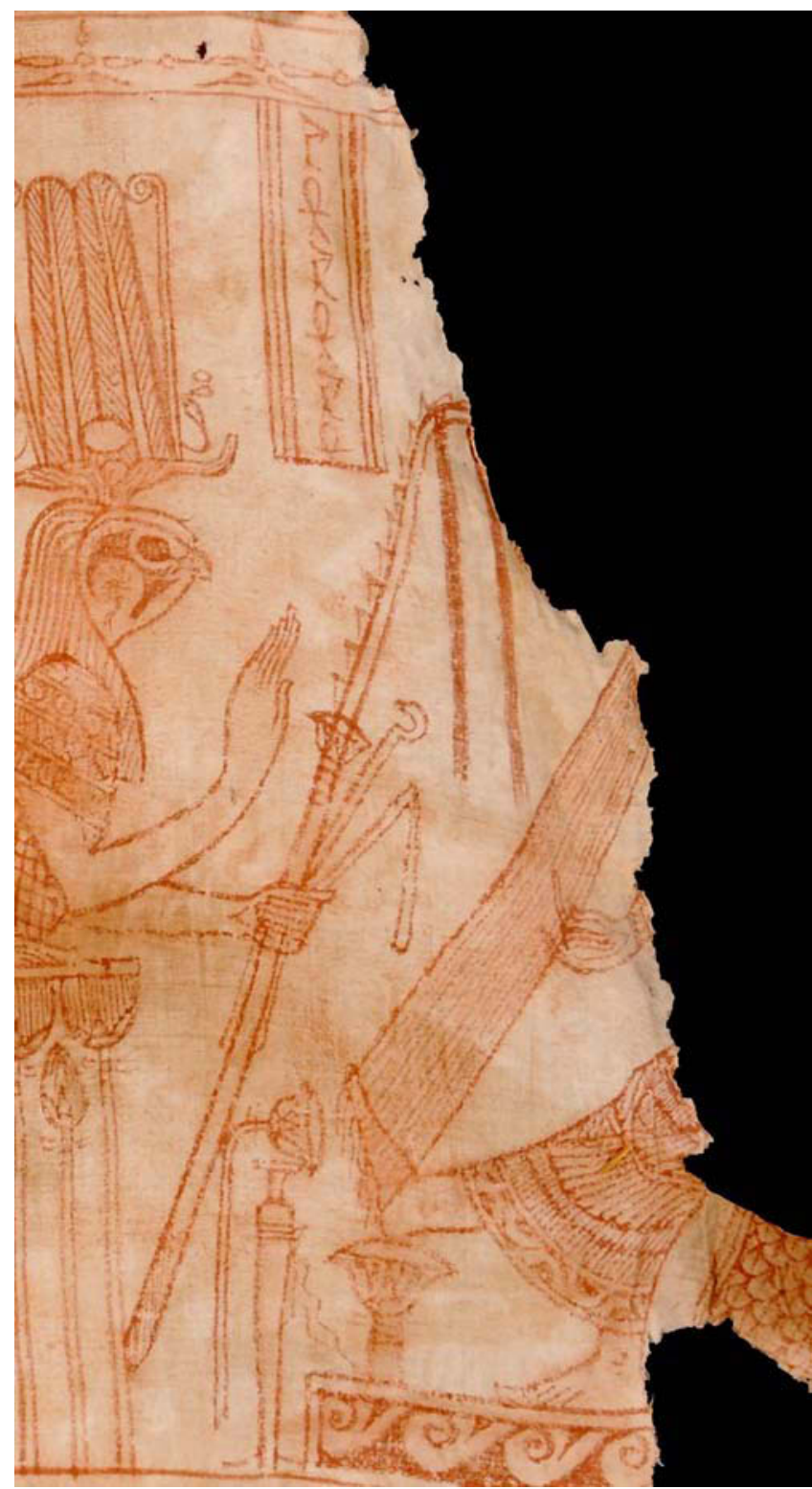

Figure 1b. Tunic from Sakkara (JE 59117), side B: depiction of Isis weaving (detail). (Photo: Ahmed Amin (C) Egyptian Museum, Cairo).

represent a two-beam loom, a ground loom, a warpweighted loom, or even a tablet loom. Moreover, this evidence has never been cited in studies concerning weaving or, in general, textiles from Egypt.

The depiction of a loom is visible on a painted tunic found in Saqqara and dated probably from the $2^{\text {nd }}$ century AD (fig. 1a)..$^{10}$ One can recognize the goddess Isis sitting on a chair. As noted by Ewa Laskowska-Kusztal, and
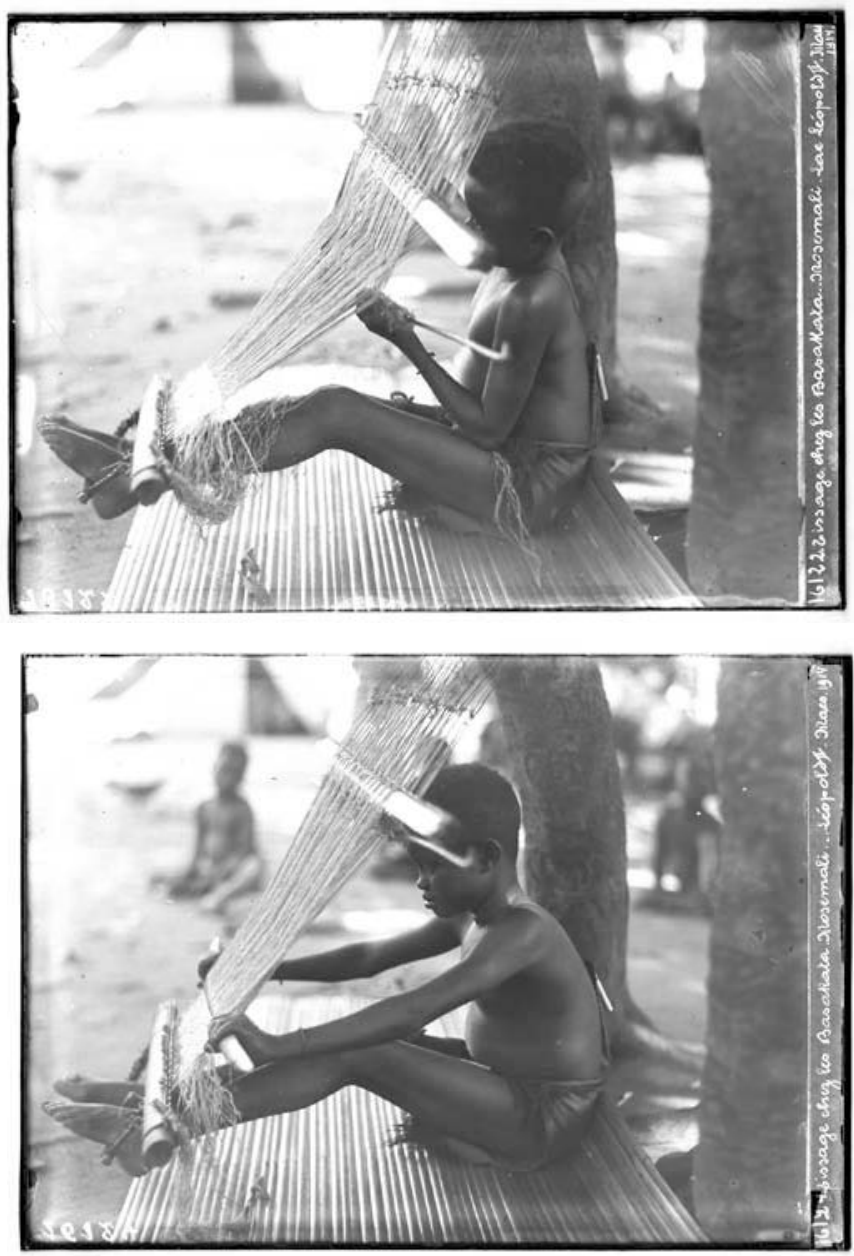

Figures 2a and 2b. Sakata boy, Zaire, weaving raffia cloth using a footstrap loom. (Photos: Philippe Tits, member of Joseph Maes' mission to the Belgian Congo (1913-1914) (C) Royal Museum for Central Africa, Tervuren).

then Françoise Labrique, Isis is weaving: she passes thread with her left hand, and her left foot, placed on a support, seems to be attached to the warp (fig. 1b). E. LaskowskaKusztal, and then Fr. Labrique, equated this unusual gesture with the action of a weaver from Niger: he is sitting on the ground and the tension of the warp is held by the back strap. ${ }^{11}$ The weaver is operating the warp with his foot. However, this interpretation does not seem to be convincing: the gestures and posture of Isis are not the same as those of the weaver from Niger, and the position of the loom is completely different.

To find another parallel for the loom represented on the tunic from Sakkara, I have also resorted to ethno-

10. On this tunic, see especially Laskowska-Kusztal 1997 and Labrique 2015; cf. also Labrique \& Papadopoulou 2012.

11. Labrique 2015, p. 218, fig. 1. 
graphic material. It seems that the posture of Isis, as well as the loom construction, corresponds much better to the way of weaving on a foot-strap loom. This kind of loom can be seen, for example, in photographs of a Sakata boy from Zaire who is weaving raffia cloth (fig. 2). ${ }^{12}$ In the foot-strap loom the warp is stretch between two parallel beams, the framework is set at an oblique angle, and the warp is kept in tension by the weaver with one or both feet. In this loom there is a single-heddle shedding device.

\section{Looms in Roman papyrological evidence: an attempt at a new interpretation}

Greek vocabulary concerning weavers and their looms attested in papyrological documentation from the Roman period is varied, and many of the terms and expressions are ambiguous.

Regarding the first two centuries AD, it is commonly admitted that the word $\gamma \varepsilon \dot{\varepsilon} \rho \delta$ เo is a general term for a weaver,

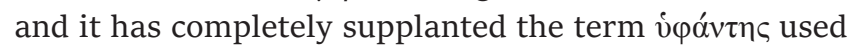
in the Ptolemaic period. ${ }^{13}$ However, the term $\gamma \varepsilon$ $\rho \delta$ io was already in use in the $2^{\text {nd }}$ century $\mathrm{BC}^{14}$ although we do not know the exact difference in meaning between the two terms. ${ }^{15}$ It seems that the craft of specialised linen weavers, attested in Ptolemaic as well as in Roman times, and

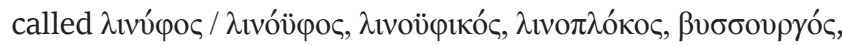
was not connected to any specific loom, but rather to the way of weaving the warp threads which determines the look of textile. ${ }^{16}$

Regarding vocabulary connected to the loom, the word i $\sigma$ ó $\varsigma$ in the Roman period keeps the ambiguity already attested in the Hellenistic period, and besides being a loom, it could specify a piece of textile, probably referring to its rectangular shape. Nevertheless, in many texts the term i $\sigma \tau$ óc is accompanied by other designations, such as

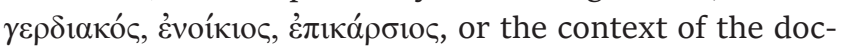

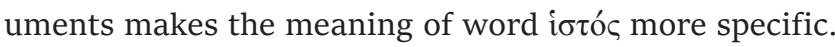
In addition, some new specialised terms for the weaver's

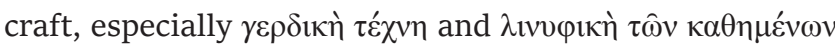
$\tau \varepsilon_{\chi}^{\prime} \chi \nu$, are mentioned in apprenticeship contracts and they could be related to work on a specific loom.

\section{Looms}

\section{íđóc (histos)}

Many sales agreements for looms were noted by the record office (grapheion) at Tebtynis (Fayyum Oasis) between AD 42 and 47. Seventeen of these contracts concern an

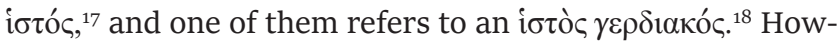
ever, it is not obvious if this distinction is deliberate and reflects different types of loom, or whether i $\sigma \tau$ óc is only a

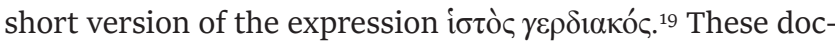
uments record administrative fees for sales agreements, but unfortunately do not provide any description of the looms. Whereas one of the contracts notes the price of an i $\sigma$ tó $\varsigma$ as 24 drachmas, ${ }^{20}$ another one concerns a contract "for nursing (a slave child) and for a loan of 12 drachmas and 2 keramia of wine, for a total of 16 silver drach-

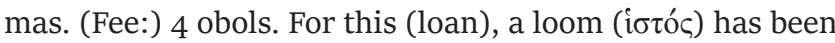
given as security". ${ }^{21}$ It could therefore be supposed that the loom, referred to in this document as a guarantee, is worth at least 16 silver drachmas. The difference in price

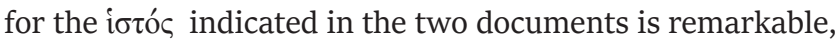

12. Picton \& Mack 1989, p. 47 and 88.

13. Cf. Wipszycka 1965, p. 103; Ruffing 2008, p. 470-487; Droß-Krüpe 2011, p. 58-86.

14. For example, $P$. Tebt. I 16, 48 ( $2^{\text {nd }}$ century BC).

15. Maybe the appearance of the term $\gamma \bar{\varepsilon} \rho \delta$ ioৎ was connected with an increasing use in Egypt of a specific loom: the vertical twobeam loom? and the need to distinguish weavers working on this loom from other weavers, which used a ground loom and/ or a warp-weighted loom? A lack of proof means that this interpretation remains hypothetical.

16. About these specialised weavers, cf. Wipszycka 1965, p. 103-110; Ruffing 2008, p. 466-468, 640-647; Droß-Krüpe 2011, p. 93-102.

17. P. Mich. II 123 recto, col II, 20, col. III, 19, col. VII 18, col. VIII 29, col. XI 5, col. XIV 12, 15, 26, col. XV 13, 24, col. XVI 10 (AD 45-46); P. Mich. II 125, 10 (AD 45); P. Mich. II 128, III 6, 21 (AD 46-47); P. Mich. V 240, 27, 41 (AD 46-47).

18. P. Mich. II 121 verso, col. VII, 3 (AD 42).

19. For this last option, see Wipszycka 1965, p. 52 and Droß-Krüpe 2015, p. 148. Nevertheless, because of all this ambiguity, the

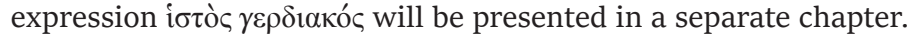

20. P. Mich. II 123 recto, col. XIV 26.

21. P. Mich. V 240, 64-65 (AD 46-47): English translation by the editors of this text: E.M. Husselman, A.E.R. Boak and W.F. Edgerton. 
but we do not know if it is related to different kinds of loom, to their dimensions or perhaps to their condition.

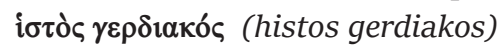

Many papyrological documents refer to the sale or rent

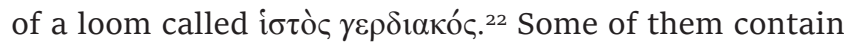
detailed description of the loom or its price. In the contract of sale of a loom to the weaver Tryphon from Oxyrhynchus, concluded in AD 54 ( $P$. Oxy. II 264, 3), the seller Ammonios specifies "I agree that I have sold to you the

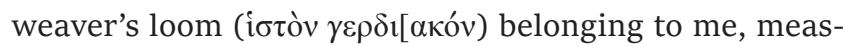
uring three weaver's cubits less two palms, and containing two cross-beams ( $\dot{\alpha} v \tau^{\prime} \alpha$ ) and two upright beams

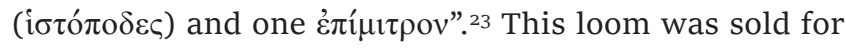
20 silver drachmas.

A similar description of a loom is found in a rental contract ( $P$. Oxy. XXXVI 2773, 11-14; AD 82): “I concede you

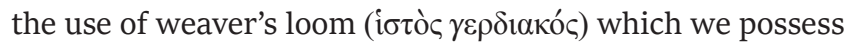
measuring 3 cubits less 2 palms, comprising 2 cross-beams

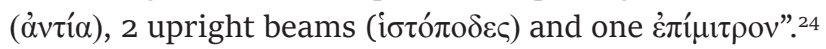

The same kind of loom, but larger in size, is described in a sales contract dated to $\mathrm{AD} 101$ (P. Oxy.Hels. 34, 2-9): "I agree that I have sold you the weaver's loom belonging to me, containing two cross-beams ( $\left.{ }_{\alpha} v \tau i ́ \alpha\right)$, two upright beams

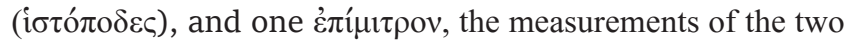
cross-beams being three and a half cubits for the one, and three cubits and ten digits for other". ${ }^{25}$ This loom was sold for 28 silver drachmas.

Two terms that are used in the above descriptions of looms need a comment. The first one is ávtíov, the word used in classical Greek texts for an upper cross-beam in the warp-weighted loom. ${ }^{26}$ As Maarit Kaimio remarks in her publication of $P$. Oxy.Hels. 34, it seems probable that in the case of a two-beam loom "the lower beam also bore the same name". ${ }^{27}$ Bernard P. Grenfell and Arthur S. Hunt, as well as Ursula Schlag, in their editions of the documents

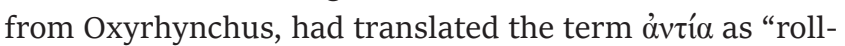
ers", ${ }^{28}$ making, without doubt, a reference to the movement of the upper cross-beam in the warp-weighted loom. ${ }^{29}$ This interpretation fits well with what we know about the Roman version of the two-beam loom with revolving beams. The meaning of the second term, '̇ंí $\mu 1 \tau \rho o v$, has been also analysed by M. Kaimio and she identified it in a convincing manner as a "heddle rod". ${ }^{\circ}$

M. Kaimio notes in her publication of P. Oxy.Hels. 34 that the measurement of the loom indicated in all these documents is probably the length of the cross-beams. ${ }^{31}$ Although a calculation of the weaver's cubit used in the Roman period is still an open question, Antoine Pierre Hirsch in his $\mathrm{PhD}$ dissertation remarks, regarding clothweaver cubits mentioned in Ptolemaic and Roman period texts, that we do not know which cubit system was involved. ${ }^{32}$ According to his interpretation of the metrological papyrus from Oxyrhynchus (P. Oxy. IV, 669; AD 285-287), the value of the weaver's cubit can vary from $37.5 \mathrm{~cm}$ to $43.75 \mathrm{~cm} .{ }^{33}$ So, we can approximately calculate the width of the looms mentioned in P. Oxy. II 264 and P. Oxy. XXXVI 2773 as between $97.5 \mathrm{~cm}$ and 113.75 $\mathrm{cm}$. The cross-beams of the loom from P. Oxy.Hels. 34 had slightly different lengths: the first one between $131.25 \mathrm{~cm}$ and $153.12 \mathrm{~cm}$, and the second one between $130.5 \mathrm{~cm}$ and $152.25 \mathrm{~cm}$. Taking the dimensions of these looms into consideration, we can suppose that they were used to weave "Roman-style" tunics made of two rectangular pieces of fabric sewn together, ${ }^{34}$ or to manufacture shawls, veils or furnishing textiles.

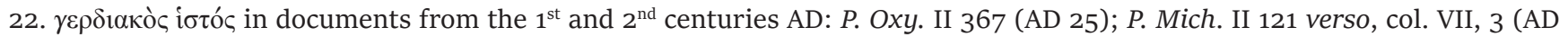
42); P. Oxy. XXXVI 2773 (AD 82); P. Oxy. II 264, 3 (AD 54); P. Oxy.Hels. 34 (AD 101); P. Oxy. III 646 (AD 117-138); P. Oxy. X 1269 (AD 101-125); SPP XXII 40 (AD 150).

23. Translation by editors B.P. Grenfell, A.S. Hunt (P. Oxy. II, p. 235) with my modifications.

24. Translation by editor U. Schlag (P. Oxy. XXXVI, p. 66) with my modifications.

25. Translation by editor M. Kaimio (P. Oxy.Hels. p. 127) with my modifications.

26. For example: Aristophanes, Thesmophoriazusae, 822.

27. P. Oxy.Hels. p. 128.

28. P. Oxy. II, p. 235; P. Oxy. XXXVI, p. 66.

29. Cf. Broudy 1979, p. 23-25; Ciszuk \& Hammarlund 2008, p. 122.

30. P. Oxy.Hels. p. 128-129.

31. Loc. cit.

32. Hirsch 2013, p. 96.

33. Ibid., table 23, p. 84. The weaver's cubit mentioned in $P$. Oxy. IV 669 contained most likely five palms, so depending on the cubit system, one palm equals $7.5 \mathrm{~cm}$ to $8.75 \mathrm{~cm}$. One palm was divided in four fingers, from $1.8 \mathrm{~cm}$ to $2.1 \mathrm{~cm}$.

34. About tunics used in Egypt at the Roman period, see Mossakowska-Gaubert 2017. 


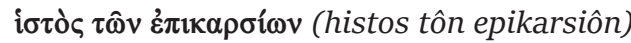

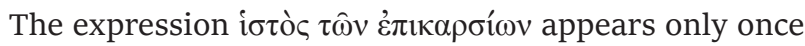
in the papyrological documentation (P. Oxy. XLII 3062, 3-4, $1^{\text {st }}$ century AD) and it seems to be related to the manufac-

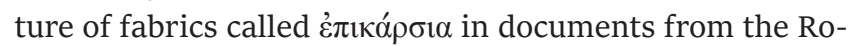
man and Byzantine periods. The papyrological evidence of these terms has recently been studied by Kerstin DroßKrüpe 35 and she concludes, in a convincing way, that tex-

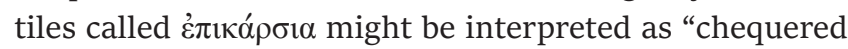
garments", produced by any weaving technique. The i $\sigma$ tò $\varsigma$

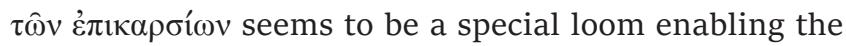
weavers to produce more complex types of check pattern fabrics, such as twill or diamond twill: according to K. Droß-Krüpe it was probably a two-beam loom with two or more shed sticks. We would add that it could also be a warp-weighted loom with three heddle rods. ${ }^{36}$

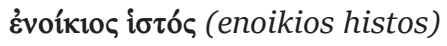

The looms mentioned in the documents cited above were most likely used by professional weavers, however, looms were also used for domestic purposes. One of the documents from the Roman period (P. Oxy. XIV 1737, 8, 22, $42 ; 2^{\text {nd }}-3^{\text {th }}$ century AD) relates directly to a "house loom"

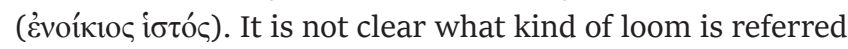
to in this document, perhaps a simple ground loom?

\section{The weaver's craft}

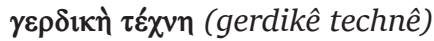

In the Roman era documents we find numerous apprenticeship contracts (didaskalikai or cheirographai) for the "weaver's craft", $\gamma \varepsilon \rho \delta ı \eta_{\eta} \tau \dot{\varepsilon} \chi \nu \eta .{ }^{37}$ These contracts contain detailed agreements concerning the financial conditions of training, accommodation etc., but they do not mention any type of weaving loom or other technical information about the skills to be learned. Most frequently the apprenticeship lasts from one to three years, ${ }^{38}$ though some contracts concern a training period of four ${ }^{39}$ or five years..$^{\circ}$ It seems that in the case of longer contracts, after two or three years of apprenticeship, a trainee became a journeyman to the master, and got a salary. It is not however clear why the duration of training is so variable. On the one hand, we have no proof that an apprentice learned only in one workshop, and on the other, it might be that he/she already had some weaving experience so his/her training could be shorter than that of a beginner. Nevertheless, it seems that three years was enough time for a basic training in the $\gamma \varepsilon \rho \delta ı \eta^{\prime} \tau \dot{\varepsilon} \chi \nu \eta$, and five years for becoming a specialised weaver. In comparison with other professional trainings, it seems a quiet long period, ${ }^{41}$ which would be proof of high specialisation of the required skills.

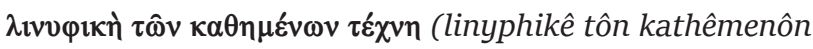 technê)}

A contract of apprenticeship (cheirographon) registered in P. Fouad 37 (AD 48), between a weaver named Menodorus and a certain Fuscus, concerns teaching, over two years "the craft of the seated linen weavers" (1. 4):

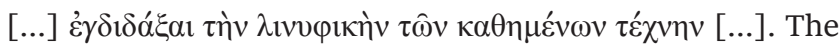
trainee is to receive payment during training of 48 drachmas each year.

In her book of 1965, Ewa Wipszycka was the first to pay attention to the exceptional feature of this document, clearly concerning some new technological concept. ${ }^{42}$ She interpreted it as proof of the use of an improved version of the horizontal loom, probably with the raised pegs, allowing the weaver to sit when using the loom. She excluded the idea that this contract involved a two-beam vertical loom used since the Pharaonic period, because in the case of such a loom the weaver was seated only when starting the work. In addition, this loom had been known in Egypt from a long time, and it would not be necessary to specify in a contract that the weaver is sitting during a part of his/her work.

35. Droß-Krüpe, 2015, p. 149; Droß-Krüpe 2018.

36. About the technological possibilities of the use of warp-weighted looms, cf. Ciszuk \& Hammarlund 2008 , p. 122.

37. About apprenticeship contracts, see Bergamasco 1995, in particular for weavers: Wipszycka 1965, p. 57-63; Droß-Krüpe 2011, p. 103-120 (for an exhaustive list of contracts from the $1^{\text {st }}$ to the $3^{\text {rd }}$ century AD, see a table, p. 104-105).

38. Documents from $1^{\text {st }}$ to $2^{\text {nd }}$ century AD: P. Tebt. II, 384, 4-5 (AD 10); P. Mich. V, 346b-c (AD 12-13); P. Oxy. II 322 (AD 36) [= SB X 10236]; P. Mich. III, 170, 7 (AD 49), P. Wisc. I 4, 6 (AD 53); P. Oxy.Hels. 29 (AD 54); P. Mich. III 171, 11 (AD 58); P. Mich. III 172, 9-10 (AD 62); P. Oxy. II 275, 13 (AD 66); P. Oxy. XLI 2971 (AD 66); SB XXIV 16253, 9 (AD 97-103); P. Tebt. II 385 (AD 117); SB VI 9374 (AD 169).

39. P. Oxy. XIV 1647 (late $2^{\text {nd }}$ century AD).

40. P. Mich. II 121, 2, VIII (AD 42); P. Oxy. IV 725 (AD 183).

41. Cf. Bergamasco 1995, see especially a table p. 162-166: he noticed only two cases of six-years training: for a physician as well as for a mason's craft.

42. Wipszycka 1065, p. 49-50. 
Since 1965 many new sources and studies concerning weaving in Egypt have been published, but only Kerstin Droß-Krüpe, in her book of 2011 and then in her article from $2015,{ }^{43}$ has mentioned the contract recorded in P. Fouad 37. In her opinion, the weaver of this document is working on a two-beam vertical loom.

However, we can suppose that the expression $\lambda$ ıvvpıкi

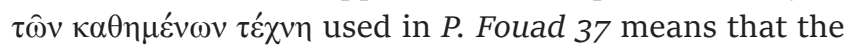
contract concerns another type of training, and probably another way of weaving and a different type of loom from that used in $\gamma \varepsilon \rho \delta ı \tau^{\prime} \tau \varepsilon_{\chi} \chi v \eta$, so often mentioned in documents from the same period. It is obvious that the weaver working on the loom from $P$. Fouad 37 was always seated, but we do not know how and where: on the ground, a bench, a chair, or maybe in a pit? In addition, a salary for the apprentice is to be paid from the first year of training, which seems to be exceptional when compared with other weaver's apprenticeship contracts dated from the $1^{\text {st }}$ century AD. Perhaps this weaving technique was not very complicated and an apprentice quickly became a journeyman.

\section{Final remarks}

Greek papyrological documentation from the $1^{\text {st }}-2^{\text {nd }}$ centuries AD features a varied vocabulary concerning weaving looms and specialised weavers. Some terms known in the Ptolemaic period disappear, but there are a lot of new ones. This differentiation of vocabulary seems to reflect technological developments and innovations in the domain of weaving.

The term i $\sigma \tau$ ć continues to be a general word for "loom", although it may sometimes take a specific meaning, most likely that of any vertical loom: a two-beam loom, without precision as to whether the beams are movable or not, and perhaps a warp-weighted loom also. It could be

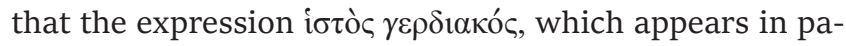
pyrological documents from the beginning of the $1^{\text {st }}$ century AD, relates specifically to a vertical loom with moving beams. If a lexical distinction between the terms i $\sigma \tau$ ò

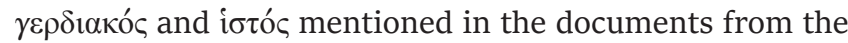
record-office at Tebtynis is intended, in this case the term

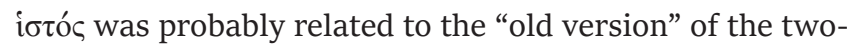
beam loom. However, we have no data to be able to estimate the extent of the use in the early Roman period of both kinds of two-beam looms. Prices of two-beam looms mentioned in the documentation depended mainly on dimensions of the apparatus.

43. Droß-Krüpe 2011, p. 40-41; Droß-Krüpe 2015, p. 148.
Another kind of loom also appears in the $1^{\text {st }}$ century AD.

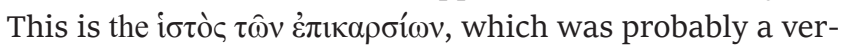
tical loom with a developed shed rods system, or a warpweighted loom with three heddle rods, used to produce, for example, diamond twill. We can suppose that the simple horizontal loom, used mainly for domestic purposes in

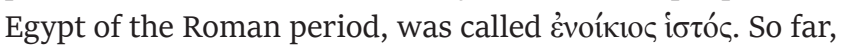
we cannot identify any specific denomination for a warpweighted loom, nor for a tablet loom, in the Greek vocabulary used in Egypt in the early Roman era.

The expression $\gamma \varepsilon \rho \delta ı \eta^{\prime} \tau \varepsilon_{\chi}^{\prime} \chi \eta \eta$ probably specifies the craft of a weaver working on any vertical two-beam loom. The lack of apprenticeship contracts concerning weavers spe-

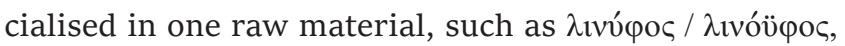

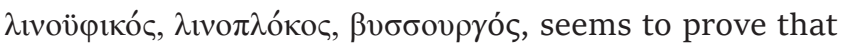
they worked on any kind of loom, most likely a vertical loom, and they received training in $\gamma \varepsilon \rho \delta ı \tau^{\prime} \tau \varepsilon_{\chi} \chi \eta \eta$. However,

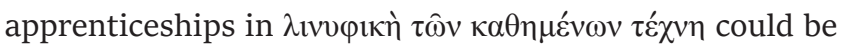
proof of the introduction into Egypt of a new kind of loom to produce linen textiles. It is tempting to connect the loom used by the "seated linen weaver" of P. Fouad. 37 with a foot-strap loom. This kind of loom could be identified in the representation on the tunic from Sakkara.

All identifications proposed in this article must remain hypothetical, but we hope that new data from papyrological, iconographical and archaeological sources will clarify the issue of looms used in Egypt in the Roman period.

\section{Abbreviations}

All papyrological works and all references to papyri, ostraca, etc. follow J.F. Oates, R.S. Bagnall, S.J. Clackson, A.A. O’Brien, J.D. Sosin, T.G. Wilfong \& K.A. Worp (eds.), Checklist of Greek, Latin, Demotic and Coptic Papyri, Ostraca and Tablets. Available at: https://library.duke.edu/rubenstein/scriptorium/ papyrus/texts/clist_papyri.html (continually updated)

\section{Bibliography}

Bergamasco, M. (1995) "Le $\delta ı \delta \alpha \sigma x \alpha \lambda \iota x \alpha i ́$ nella ricerca attuale”, Aegyptus 75, p. 99-167.

Broudy, E. (1979) The Book of Looms. A History of the Handloom from Ancient Times to the Present, New York (reprinted in 1993 by the University Press of New England, Hanover - London). 
Ciszuk, M. \& Hammarlund, L. (2008) "Roman Looms A Study of Craftsmanship and Technology in the Mons Claudianus Textile Project", in C. Alfaro \& L. Karali (eds.), Purpureae vestes II. Vestidos, textiles y tintes: estudios sobre la producción de bienes de consumo en la Antigüedad : actas del II symposium internacional sobre textiles y tintes del Mediterráneo en el mundo antiguo (Atenas, 24 al 26 de noviembre, 2005), Valencia, p. 119-133.

Droß-Krüpe, K. (2011) Wolle-Weber-Wirtschaft. Die Textil produktion der römischen Kaiserzeit im Spiegel der papyrologischen Überlieferung. Philippika 46, Wiesbaden.

Droß-Krüpe, K. (2015) "Textile tools in papyri from Roman Egypt”, in A. De Moor, C. Fluck \& P. Linscheid (eds.), Textiles, Tools, and Techniques of the $1^{\text {st }}$ Millennium AD from Egypt and Neighbouring Countries. Proceedings of the 8th conference of the research group 'Textiles from the Nile Valley', Antwerp, 4-6 October 2013, Tielt, p. 147-149.

Droß-Krüpe, K. (2018) "Kleinkariert, großkariert, feinkariert? Überlegungen zu einer Neuinterpretation

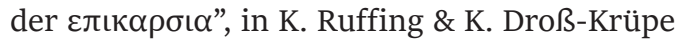
(eds.), Emas non quod opus est, sed quod necesse est. Beiträge zur Wirtschafts-, Sozial-, Rezeptionsund Wissenschaftsgeschichte der Antike. Festschrift für Hans-Joachim Drexhage zum 70. Geburtstag. Philippika 6o, Wiesbaden, p. 117-130.

Gradel, C., Letellier-Willemin, L. \& Tallet, G. (2012) " 'Une laine bien plus belle et douce que celle des moutons' à el-Deir (oasis de Kharga, Égypte) : le coton au cœur de l'économie oasienne à l'époque romaine", in S. Guédon (ed.), Entre Afrique et Égypte. Relations et échanges entre les espaces au sud de la Méditerranée à l'époque romaine. Scripta Antiqua 49, Bordeaux, p. 119-141.

Hirsch, A.P. (2013) Ancient Egyptian Cubits - Origin and Evolution, PhD, University of Toronto. Available at: https://tspace.library.utoronto.ca/ bitstream/1807/35848/10/Hirsch Antoine P 201306 PhD thesis.pdf) (last checked: 28/6/2019)

Kamp, B.J. \& Vogelsang-Eastwood, G. (2001) The Ancient Textile Industry at Amarna. Egypt Exploration Society Excavation Memoir 68, London.

Labrique, Fr. (2015) "La tunique historiée de Saqqara: Maât-Alêtheia versus Isis-Perséphone”, in Fr. Colin, O. Huck \& S. Vanséveren (eds.), Interpretatio. Collections de l'Université de Strasbourg : Études d'archéologie et d'histoire ancienne, Paris, p. 231- 264.
Labrique, Fr. \& Papadopoulou, I. (2012) "Les déesses au métier : Isis et Perséphone tisserandes", in V. Bers, D. Elmer, D. Frame \& L. Muellner (eds.), Donum natalicium digitaliter confectum Gregorio Nagy septuagenario a discipulis collegis familiaribus oblatum. A Virtual Birthday Gift Presented to Gregory Nagy on Turning Seventy by his Students, Colleagues and Friends, Washington, D.C. Available at: https:// chs.harvard.edu/CHS/article/display/4835 (last checked 28/6/2019).

Laskowska-Kusztal, E. (1997) "Encore sur la tunique liturgique de Saqqara”, in Essays in Honour of Prof. Dr. Jadwiga Lipińska. Warsaw Egyptological Studies 1, Warsaw, p. 363-370.

Letellier-Willemin, F. (2020) “Tackling the Technical History of the Textiles of El-Deir, Kharga Oasis, the Western Desert of Egypt", in M. MossakowskaGaubert (ed.), Egyptian Textiles and Their Production: 'Word' and 'Object' (Hellenistic, Roman and Byzantine Periods). Zea Books 2020, Lincoln, p. 37-48. Available at: http://digitalcommons.unl.edu/etpwo

Mossakowska-Gaubert, M. (2017) “Tunics Worn in Egypt in Roman and Byzantine Times: the Greek Vocabulary", in S. Gaspa, C. Michel \& M.-L. Nosch (eds.), Textile Terminologies from the Orient to the Mediterranean and Europe 1000 BC - AD 1000. Zea Books 56, Lincoln, p. 321-345. Available at: https:// digitalcommons.unl.edu/texterm/20/

Picton, J. \& Mack, J. (1989) African Textiles (2 ${ }^{\text {nd }}$ edition), London.

Ruffing, K. (2008) Die berufliche Spezialisierung in Handel und Handwerk: Untersuchungen zu ihrer Entwicklung und zu ihren Bedingungen in der römischen Kaiserzeit im östlichen Mittelmeerraum auf der Grundlage griechischer Inschriften und Papyri. PHAROS 24, Rahden/Westf.

Sigl, J. (2016) "Looms in the Architecture of Monk. Dwellings from Coptic Egypt”, in L. Mahmoud \& A. Mansour (eds.), Copts in the Egyptian Society before and after Muslim Conquest. Studies in Calligraphy and Writings 19, Alexandria, p. 59-79.

Sigl, J. (2020) "Egyptian Pit-looms from the Late First Millennium AD - attempts in reconstruction from the archaeological evidence", in M. MossakowskaGaubert (ed.), Egyptian Textiles and Their Production: 'Word' and 'Object' (Hellenistic, Roman and Byzantine Periods). Zea Books 2020, Lincoln, pp. 22-35. Available at: http://digitalcommons.unl.edu/etpwo 
Vogelsang-Eastwood, G. (2000) “Textiles”, in P.T. Nicholson \& I. Shaw (eds.), Ancient Egyptian Materials and Technology, New York, p. 268-298.

Wild, J.P. (1992) “The Roman Loom in Western Europe: The Evidence of Art and Archaeology", Vlaamse Vereniging voor Oud en Hedendaags Textiel, Bulletin 1992, p. 12-17.

Wild, J.P., Wild, F. \& Clapham, A. (2008) "Roman Cotton Revised”, in C. Alfaro \& L. Karali (eds.),
Purpureae vestes II. Vestidos, textiles y tintes: estudios sobre la producción de bienes de consumo en la Antigüedad : actas del II symposium internacional sobre textiles y tintes del Mediterráneo en el mundo antiguo (Atenas, 24 al 26 de noviembre, 2005), Valencia, p. 143-147.

Wipszycka, E. (1965) L’industrie textile dans l'Égypte romaine. Archiwum Filologiczne 9, Wrocław - Warsaw - Cracow. 